\title{
Determinant Factors in Building Youth Character
}

\author{
V. R. Hasanah, J. S. Ardiwinata, E. Sudiapermana \\ Department of Nonformal Education \\ Universitas Pendidikan Indonesia \\ Bandung, INDONESIA \\ viena@upi.edu
}

\begin{abstract}
This study aims to find out determinant factors building youth character in training with religion, values basis by exploring training management, youth character built through the training, and strategies and methods of training. This study employed qualitative approach by using data exploration and used multiple techniques of data collections, including observation, interview and focused group discussion. The results showed that environment, training, method, trainer and facilitator consistency in setting examples and character, motivation given during the training, team coordination and partnership factors were the main determinant aspects caused the changing in the character of the youth in the training.
\end{abstract}

Keywords: determinant factors, training with religion value basis, youth character

\section{INTRODUCTION}

The younger generation is the agent of a nation that is in need of quality improvement, particularly in terms of mental and character building in order to create a strong generation and is able to compete globally. Youths have a strategic position, both as the agent of development and as the successor of this development in the future. The number of youth in Indonesia ages 16-30 is approximately 57.81 million or $25.04 \%$ of the Indonesian population, which is 230.87 million. The smallest percentage of the number of youth compared to that the population ages under 16 years is $30.88 \%$ and that above 30 years is 44.08 $\%$. Despite the fact, the number of the youth increases compared to that in 2007 (57.17 million) and in 2008 (56.73 million) [1]. (Susenas data, 2009, kemenegpora, 2010, page v).

Literally, a youth is defined as the time of life between childhood and maturity, early maturity, the state of being young or immature, or inexperienced, the freshness and vitality characteristic of a young person. Furthermore, Syamsudin (2008) mentioned that the role of the youth is central in the changing, considering that youths have dynamic passion [2]. Particular features of a youth are burning passion in that sometimes they are lack of consideration of the consequence of the decision they have taken. Physically, youths are stronger than people above their ages.

The meaning of character refers to the way of thinking and to behave particularly to each individual in life, in family, society, and nation. Character is a particular feature of a thing or an individual (human). This particular feature is original and rooted in the character of that thing or individual which is used as a motor of how to act, behave, utter, and respond to something (Mulyasa, 2014:10) [3].

The role of family and the surrounding environment affect the formation of youth. (Catherine C. McDonald et.al (2011) [4] Other studies have shown that the formation of youth, influenced by the control of social political and environmental empowerment and family (D. Briand christens (2012). [5] Other studies have shown that character's youth is an important aspect that must be developed. One of which is through the participation of youth in various activities outside of school.[6] [7] [8] [9] [10] (Jennifer P. Agans et.all (2014); Edmond P. Bowers et al (2010); G. John Geldhof et al (2014)). N Park (2004); (2009) reinforces the opinion of Bandura (1977); Sprafkin, Liebert, and Puolos, (1975) that good role models are the key of character building. Other research reveals that it is one of the factors forming a strong character is the strength of theological value of religion. (N. Park, C. Peterson. (2006)) [11]. This study focuses on the formation of good character, of the youth through youth activities at one unit of religious values-based education that SSG Training DT.

Daarut Tauhid Islamic Boarding School (DT) has a concept that is associated with real miniature of life. This school puts an emphasis on the activity to realize Islamic teaching which is down to earth, does not only focus on its theoretical teaching, but also its practices, real evidence and examples so that the benefit gained can give actual advantages for people. By having this concept, it is expected that the beauty of Islamic teaching and the Islamic solution to actual problems faced by people in their lives can be discussed and understood. DaarutTauhid Islamic Boarding School with the vision of ahli dzikir (Dzikr experts), ahli fikir (philosophers), and ahli ikhtiar (hard worker) attempts to combine these three potentials to make the school become a boarding school with bless from Allah, as the center of knowledge for production where the people have the character of amarma'rufnahimungkar (to keep asking people to do a good deed and to prevent people from misbehaving). This vision is put into actual within several missions, including, firstly to make the concept of heart and mind management as the concept to change the character, to tranquil the heart, to keep up the spirit of education and training as well as the fostering program; secondly, to direct organizational activity towards a blessed city Islamic boarding school, and towards Bandung with Dignity; thirdly, to advance economic factor of DaarutTauhid by developing entrepreneurship character, products and services; fourthly, to produce human resources with good working ethos, ready to create something so that the school can be the center of education and training as well as fostering agent.

DaarutTauhid Bandung, as one of modern Islamic Boarding Schools, provides a program of a special training for youths who want to increase their knowledge in terms of religion, science, and life skills compared to other youths in common. All related activities can support the youths to improve their potentials and to build their 
characters to become strong and gentle, sincere, honest, brave, modest, independent, discipline, true to himself and true to Allah.

Basic Education and Training (Diklatsar) of the Santri Siap Guna (SSG) or literally translated as 'Students Ready to Use' which is equivalent to oblige students is one of the training forms conducted by DaarutTauhid Islamic Boarding School aims to foster and create young generation with born leader and independent character, by focusing more on their characters so that a network of Islamic socialization development can be achieved in the society. This program is also set for structuring regeneration and fostering the youths and to be capable of motivating, stabilizing, and integrating society; the generation of Ahli Dzikir, Ahli Fikir and Ahli Ikhtiar.

Basic Education and Training of SSG DT is a program accommodating all levels of society from varying status, age and social levels. The training of SSG is designed to build and educate the agent of Islamic socialization with good and strong character and is expected that the students be the agent of change and set good examples for society (Gymnastiar, 2013) [12].

Therefore, this research was aimed to explore data regarding some following questions:

- How does the management of basic education and training in SSG DT Bandung develop the character of good and strong (BAKU) of the youth?

- How those BAKU characters are developed in basic education and training of SSG DT?

- What are the strategies and methods to use in order to develop the character of BAKU through the training of basic education and training of SSG DT?

- What are determinant factors building youth character in basic education and training of SSG DT?

\section{METHODOLOGY}

This research was conducted in the Daarut Tauhid Islamic Boarding School in Jalan Geger Kalong Girang number 167, Kelurahan Sukasari, Kecamatan Isola, Bandung. This place was chosen because this place has a concept of training and fostering model with the basis of religion, which is particularly different from other trainings in common. The training is called Diklatsar SSG DT.

The participants involved in the study were five people who were expected to give information related to the training of trainers of SSG DT Bandung. All participants included the supervisor, manager, trainer, participant and alumni of training of SSG. The study was initiated by doing introductions, data collection and triangulation (interview, observation, and documentary study), and the analysis of data. This study employed qualitative design and used multiple techniques of data collections, including observation, interview, documentary study, and focused group discussion.

The first interview was conducted in order to carry out the data regarding the description of management of training of SSG DT. The source of the data consisted of five participants as aforementioned. The observation was conducted by collecting the data of the implementation of the training of SSG DT and its effects on the character's changing. The instruments used in order to observe is the observation reference.

Focused Group Discussion was done in order to dig out the data further, especially in terms of the materials used in the training related to youth character building. In the last stage, the researcher conducted documentary study by collecting the profile of the institution, the data of the participants of Diklatsar SSG DT, both the present students and the alumni. Focus Group Discussion (FGD) was carried out by involving the four elements of SSG DT training as follows.
a. Supervisor
b. Trainer
c. Facilitator
d. Alumni

There were 12 people doing the FGD. The discussion was conducted in the institution and the topic of the FGD was centered on the character built through the training of SSG DT.

\section{RESULTS}

\section{A. Profile of Diklat SSG DT}

SSG DT was initiated by KH. Abdullah Gymnastyar (AA Gym) on April 251999 in which the vision is oriented to serve society in terms of Islamic socialization, education, economy, and social. Apart from that, SSG DT is prepared for regeneration and foster of independent young generation, enable them to motivate, stabilize and integrate society and have good and strong character and to become:

1) The initiator (by being sensitive, initiative, brave to do an act)

2) Independent (by being independent, acceptance of himself, to the smallest part and to start right at the time)

3) Respect (obliging, attempt to make better, sincere)

SSG DT has been distributed almost in all areas in Indonesia, reaching 10.338 members in 30 batches. In order to attain maximum condition in communication and further fostering program, structural system is formed by referring to a division of areas where the SSG DT conducts the service to society. Now, there have been 9 areas of SSG DT, namely: Tegalega, Ujung Berung, Gedebage, Cibeunying, Karees, Bojonagara, Cimahi, Kabupaten Bandung Barat, Jabobeka, outside of Bandung.

\section{B. Management of SSG DT Basic Training}

The management of SSG DT involves planning, implementation, and evaluation as well as further followup. Planning, according to Sudjana (2004:57) [13], is a systematic process when making a decision on an action to be carried out in the future. The planning process in this training includes needs identification to obtain actual data regarding the needs and conditions of the participants. Planning was conducted by organization member and the fostering of SSG, aiming to achieve the goals targeted. The results of the interview with the participants are as follows. 


\section{1) Needs analysis of SSG training,}

According to all participants were purely conducted by DT member in 1999. This training is designed by referring to a consideration that this school has paid attention to the condition of Indonesia, that despite this country has rich culture and natural resources, some society are still in bad condition. By looking at this problem, AA Gym considered that there is a need to restructure the society by making better young generation. Therefore, training with a strong intention to build, to strengthen religion, values targeting young generation is formed. By having this training, it is expected that the youth can be responsible for nation, as agent of change, leadership and entrepreneurship leading to an independent individual, being able to lead himself, to be responsible for himself, and give benefit to others. All aspects become the main needs analysis as the basis of program implementation of SSG DT Bandung.

\section{2) Curriculum}

Management of Basic Training SSG DT in the design of training program basically translates the direction and expectation of an AA Gym (KH Abdullah Gymastiar). The program, including syllabus, lesson plan, and SOP, is formulated by management of Diklatsar SSG DT under the leadership of operational Commander. The trainer then uses the curriculum and applies it to the participant. The application of the program to the participant in SSG training is various. On Saturday, for example, the program focuses on the materials such as fiqh, aqiqah, ahklak, ta'limmuta'limin the classroom, while on Sunday, the program is centered on the outdoor activities. These include outbound, self-breakthrough, obstacle training and etc. Apart from this, the program applied in the training also constitutes mentoring on Saturday night. The mentoring includes the training of marching, leadership, entrepreneurship, Qur'an and Hadiths recital and memorization, and health training.

\section{3) Participant and Trainer Recruitment}

To conduct this, the first way is by alumni networking. After graduating from the training, the alumni of SSG have an obligation to recruit an unlimited number of participants. The second way is by using social media of SSG such as Facebook, twitter, and blog as well by using DT information media such as radio, television and manual information on Friday preaching time or in DT study.

\section{4) Learning materials}

The writing of learning materials is done before the implementation of the training. The materials are written by the supervisor and the management of the institution of SSG DT training. The step of the learning materials is started by designing the syllabus, the lesson plan by including Tauhid values as oriented including good and strong character and is then continued with the writing of lesson by the team from the management and planning and development.

\section{5) Budgeting}

Budgeting is done by the management of SSG training per year. SSG training is free for the participants; however, in its application the participants are encouraged to learn to give charity showing their gratitude to Allah. Even if they have to pay for the tuition, they are charged only for the closing ceremony at the end of the program.

\section{6) Time and Material of Training}

The implementation procedure of training in SSG DT Bandung is conducted every Saturday and Sunday from16: 00 p.m. To 16:30 p.m. The materials for the training are given in and outside the classroom in line with the schedule set for the program. The materials given focus on Diniyah, Qalbu Management, Leadership, Mental of Entrepreneur, Adventure Activity, Tahsin, Tahfidz, and Entrepreneurship. All have curriculum set before the program is started.

\section{7) The Source of Material}

The source of material in the training is everything that can be used, can be experienced and can be done in SSG training. The main point of the learning is not on the physical aspect, instead it focuses on experience and action and learning based on these experiences and actions taken from the materials given in the classroom.

\section{8) Evaluation}

Scoring and Evaluation is carried out in order to see the shortcomings of the training and to view whether the application of the program can be further implemented or can be modified so that a better learning process can be attained in the future. Evaluation system can be done by the management of related tutorials. The evaluation conducted is a weekly evaluation which is conducted after the activity and at the end of the program. Scoring and evaluation systems are also conducted to find out the achievement from the training that has been implemented. In this case, one respondent commented that "evaluation is conducted after the training and at the end of the program to find out the good and bad points of the program so that the program can be improved and implemented better in the future". Another respondent declared that evaluation conducted is the cooperation between the supervisor and the management every weekend. Meanwhile, weekly evaluation is conducted in order to find out the participant presence, their participation, and its activeness, character application of BAKU and yaumiyahya.

\section{9) Success measurement:}

The level of success of the SSG DT participant according to the trainer can be seen from the participants' attendance, which is $80 \%$ presence by filing SKU DT card, passing pretest and posttest, and by following the closing ceremony for four days at the end of the program. After following the program and graduating from the training, the participants are placed in several areas set by the program and are asked to set good examples and to help society by doing good deeds in society. The facilitator declared that the success level of the training can be seen from the ability of the participants to survive and to take benefit of the training. For example, the participants become the trainer and use their knowledge in DT to strive for realizing the dream of Bandung yang bertauhid. Apart from that, another respondent stated that the success level of the SSG DT is the ability of the participant to survive until the end of the program; they gain the benefit from the program having strong and good character instilled in each individual.

\section{0) Follow-up}

The implementation of education and basic training in SSG DT Bandung, according to all participants involved in the study, has a follow-up by the formation of SSG community in each area. Apart from that, the follow-up from the training is conducted by SSG so that they are able 
to become the trainer for the implementation of SSG in the following year.

\section{1) Partnership}

SSG makes partnership with several government institutions, military, Special Corps, Police, Indonesia Military Forces, Secapa, Pusdiklat, Pusdikpasus, kodim 0609 Cimahiand several certified institutions such as social ministry.

\section{Character of Youth built through SSG Training}

Kartadinata, S (2010) describes the character education is lifelong education, as a process towards the development of human kaafah. Character Education requires role model and a process from early ages to adulthood. Application of the characters honest and sincere embedded in Diklatsar SSG DT [14]. Character education aimed at changing the human characters becomes better in knowledge attitudes and skills. The training is not only to educate participants about the character of an honest and sincere only, but also convey the values of other characters, such as tawadhu', brave, disciplined, trustworthy and professional in accordance with human life.

The results of FGD showed that the characters built through the training are good and strong character (BAKU). Good character includes honest, responsible, and modest; while Strong character involves brave, discipline, and firm. The result of the discussion showed that the basis for setting BAKU character as the goal of SSG Training is the process and expectation built together. The expectation is to have an Islamic product in which people who enter into the DT area are able to set examples and to apply these good examples to society.

TABLE I. THE CHARACTERISTICS OF BAKU CHARACTER

\begin{tabular}{|l|l|l|l|}
\hline \multicolumn{3}{|l|}{ BAKU CHARACTER } & STRONG \\
\hline GOOD & $\begin{array}{l}\text { Honest means } \\
\text { reliable until the } \\
\text { end of the life and }\end{array}$ & Brave & $\begin{array}{l}\text { Braver refers to a } \\
\text { character to } \\
\text { struggle and defend } \\
\text { what is right based } \\
\text { on religious values }\end{array}$ \\
\hline Sincere & $\begin{array}{l}\text { Sincere means } \\
\text { working only for } \\
\text { Allah }\end{array}$ & Discipline & $\begin{array}{l}\text { Discipline in } \\
\text { defined as someone } \\
\text { who always obeys } \\
\text { rules }\end{array}$ \\
\hline Modest & $\begin{array}{l}\text { Modest refers to } \\
\text { being humble and } \\
\text { not being snobby }\end{array}$ & Firm & $\begin{array}{l}\text { The firm is known } \\
\text { as being endured to } \\
\text { the situation and } \\
\text { working load }\end{array}$ \\
\hline
\end{tabular}

- The trainer explains that the character application done in the training of SSG cannot be done directly, the SSG applies the character in steps, which is done in the training process, the supervisor attempts to apply the character gradually to the participants so that habits can be formed and can be applied and in the end, the participants can gradually understand and apply BAKU character (Good and Strong) to themselves.

- BAKU character applied in SSG training is also declared by the participants. Trainer and supervisor give examples to be followed by participants. Apart from that, trainer and supervisor always applied BAKU character every week. It is started from discipline in terms of time, tasks, works, and etc.
Brave and firm in every aspect of life, being fair and modest to anyone and being responsible when carrying out a task are also among the teachings. Meanwhile, the AP stated that the application of BAKU character in the implementation of SSG training can be applied by the supervisor, management, and tutor to all training participants.

- Character application is conducted every implementation of the training program, both indoor and outdoor. Management and trainer in this training also remains the importance of discipline in the training because it is the main principle of becoming a Muslim. Alumni of trainers and participants, the way the management and the trainer in reminding them of disciplinary are by setting good examples for the participants. Apart from that, setting better examples, the second way is by making the rules obeyed by each participant and to remind each other of the rules either orally or by action.

- The way the management or trainer in fostering discipline according to respondent and alumni is by applying the rules that have been set and agreed before such as understanding the procedures, rules, and risks before doing something, to, make well organized plans, do not jump to conclusion by doing reckless things before checking and rechecking, for safety and success and always conduct things based on rules and procedures, and tries to minimize violated. It can be seen from the management and trainer to get used to coming earlier before the activity is conducted as obligated in the training. All informants stated that the "iqob" or punishment for the participants, who are coming late when following the training is another form of discipline. Punishment is realized in the forms of memorization and other equivalent tasks.

- The management or trainer always reminds of the participants to be brave and firm in all aspects. It is declared by the informants because those things include one of the keys of Muslim personality. According to the facilitator, the way the management or the trainer applied the character of being brave and firm shown as examples for the participants of the training is by giving problems to be solved by the participants. Meanwhile, the participant stated that by giving them a chance to ask and to answer the question, to give them problems to be solved and to give the students to be brave declare that the truth is the truth and what is false is false. Different from the participants, the alumni of the training stated that the application of the training in the field such as outdoor activity, self-breakthrough, obstacles and soloubivack requires all participants to be brave and firm Muslims.

- The evaluation of BAKU character is directly conducted by the trainer. The measurement of the evaluation is the graduation. The indicator of the evaluation set among others is; attendance, fully activities, involvement from the beginning to the end. A direct evaluation is done by trained and is decided by the management and supervision of the training. Evaluation of the character of BAKU that 
has been set is viewed from series activities of the participants in learning process participatory. A graduation indicator of SSG DT training participants is conducted through the trainer supervision and report. This aspect includes by doing yaumiyah, sholat berjamaah, fasting, Qur'an recital, and etc. The supervisor, trainer becomes the center of the participant's report. Furthermore, weekly report is written in order to see the participants' development during the training, considering what the students have achieved and will be achieved. The indicator of success can also be seen from testimonies from the training participants.

- Instrument of training evaluation according to trainer, facilitator and participants are set in line with the benchmark standard used. Training evaluation can also be seen from the monitoring of community formation in every area by doing the report to the supervisor and the head of DT center (Aa Gym).

- The follow-up of SSG DT training Bandung according to all respondents is by the formation of units in the area concentrated in which all alumni are spread in those units of area. The expectation is that each area will have a center of SSG where society can learn Islamic knowledge in this center, can get information regarding DT, get herbal products and books. It is expected that SSG can devote themselves in each area, to socialize Islamic knowledge and to do good deeds.

- The process of fostering program done is by following the fostering activities including regular halaqoh, special study for trainer, and special study, which are conducted by the head of DT (Aa Gym). The fostering program is carried out every week by coordinating or briefing given by the management and supervision.

- Alumni of training participants and the participants declared that there is a difference before and after the training. The participants disclosed that before participating in the training, they are just common person, cowardice, and has no purpose in life. However, after following the training, they become confident, brave, responsive, and so on. There are many advantages gained from the training. In this case, the alumni stated similar opinion regarding the benefit of the training.

The importance of the development of character education makes it necessary to develop the wide range of settings, including families, schools, communities, and the environment because it is multi-level and multi-channel (Kartadinata, S (2010). For that to maximize the educational process the character takes some setting environment that includes:

\section{1) The scope of family}

The scope of the family is a place of learning and character development made by parents and other adults in the family, especially against children

\section{2) The scope of the educational unit}

The scope of the education unit is a development and character development is done by using an integrated approach in all subjects, the development of the cultural education unit, the implementation of curricular and extracurricular activities, as well as habitual behavior in life in the educational unit. The character development is done through education units ranging from early childhood education to higher education.

\section{3) The scope of the civil society}

The scope of the civil society is a place of nurture and develop character through role models and community leaders as well as leaders of various groups of people who are members of community organizations so that the values of the characters can be internalized into the behavior and culture in everyday life.

\section{4) The scope of media}

The scope of the mass media is a system that gives a very significant influence on the public, particularly in relation to the formation of life values, attitudes, behavior, and personality or national identity.

In this case, Diklatsar SSG DT serves as education (institutions) that foster character learners.

1)Strategies and Methods of learning applied in SSG DT basic training

Learning strategies and methods are designed to attain learning goals. Methods and Techniques used in SSG DT training are chosen based on the needs of the participants and is done in line with the needs analysis in the field, centering on the participants and the learners. This is also done based on the needs of the participants. The methods applied in the training are lecturing, discussion, question and answer, participative method, reflection and experienced-based learning.

Realm built on learning approach to training character values is the realm of affection. This affection condition will be realized if they can be opened to the cognitive process through various interactions that occur between the trainers with the trainees. A psychological personality study conducted by David Kolb is a modern learning concept, known as Kolb's Learning Cycle, which begins with the learner experience of an event, felt as emotion (Leslie, R (2000: 23) [14]. The model shown in the following picture:

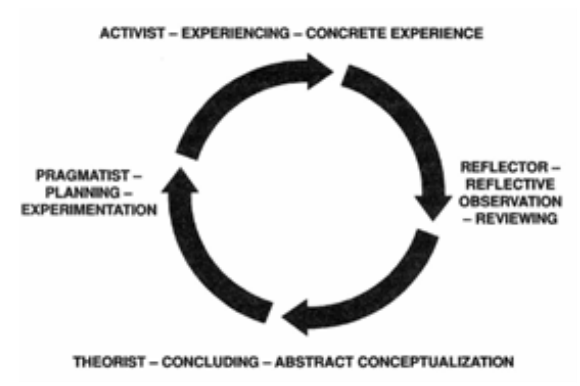

Fig. 1. Kolb's Learning Cycle

The process of opening the experience to certain events, will take all conditions into several aspects of the circle. Through a reflection of the experience, the trainees are invited to find out why this happens? What caused it? How to cope? And so on up together can draw conclusions on the incident. The last step is to experiment or try to act, to do something in the future, perhaps with the same situation. 
When connected to the strategy and methods of learning at the workshop held in building character values, DT SSG Training trainees are given stimulation to experiences and events that happened at this time. From this experience, will be obtained "gap" between the expectations and the events that happened at this time or also referred to as a problem. Indicators of these problems are reflected together, as well as the existence of human beings in the world as God Almighty.

2) Determinant factors indicating the success of the training of SSG DT

Description of the management as well as the training process identifies determinant factors indicating building the character of the youth in the SSG DT training. Those factors are elaborated below.

\section{- Environment factor}

DT Islamic Boarding School, where the training is conducted becomes the main supporting factor in youth character building. Learning facilities in DT are very conducive and supportive of the program of the training which is closely related to religion values. The facilities of DT such as the mosque, Daarul Hajj hall, Eco Pesantren and all situations support the participants to build positive character. Apart from that, the implementation of the program makes use of the outdoor situation for almost every activity, making the youth get close to the nature and to find their true character.

Kemdiknas (2011: 13) explains that the educational process is based on the totality of the psychological character that covers the full potential of the human individual (cognitive, affective, psychomotor) and function in the context of the totality of sociocultural interaction in the family, education and community units. A training program based on character and religious values, have a strong influence also on the environment. Someone would change if the environment supports it. Efforts made by Diklatsar SSG DT in providing training feedback to alumni, which is to always hang out and interact with people of good character [15].

\section{- Training Methods}

The training methods become the determining factor in building character of the youth because in three months training, in each meeting (Saturday and Sunday), the trainer applied varying methods and gave the ice breaking in several activities. The methods include drilling to pray, learning by doing, reflecting which is closely related to the BAKU character by being honest, sincere, modest as parts of Good character as well as Strong character including brave, discipline, and firm.

The training material is the cornerstone of the training program, because the training material contains ideas or opinions related to insight and knowledge. The training materials that are constructed in Diklatsar SSG focus on Islamic values. Expressed by M. Halstead (2004) [16] regarding the educational dimension of Islam that one of them is to build individual character. Diklatsar SSG build several focus themes are: a) material or directly on the training content of religious materials such as jurisprudence, faith, morals are also equipped with the material building motivation, social work and entrepreneurship; b) The materials are arranged thematically, not rigid and flexible, adapted to the needs of participant's palate. However, all of the training materials sourced from the Al-Quran and Al-Hadith adapted to everyday life.

Sauri, S (2014: 614) [16] in his book learning models based on Islamic values, said the characters of religious values such as:

1) Faith, 2) Worship, 3) Takwa, 4) good values, 5) Honestly, 6) Tolerance, 7) Discipline, 8) Creative, 9) Independent, 10) democratic, 11) Curiosity, 12) the national spirit, 13) Love homeland, 14) Appreciating the achievements, 15) Friendly / communicative, 16) Love peace, 17) Likes to read, 18) Care for the environment, 19) Social Care, 20) Responsibility.

In line with the opinion of the above, the values of character are built on religious-based training program has been relevant. Spiritual values were built in the Diklatsar SSG DT, derived from the Quran and Al-Hadith as a hint of human life.

1)Trainer and facilitator consistency in setting examples and character

Consistency and discipline of all management and trainer are other keys. The trainers are the alumni of SSG training that has also become another determining factor. The trainer setting good examples in the training becomes the important for the strength of the training.

The trainer is a facilitator that provides or deliver insight and knowledge as well as a role model for the trainee. A trainer must be proficient in building a learning climate, encourage participants to think and act. According to Beard, C and JP Wilson (2001: 19) [17] explain that:

As a training professional, it is important to recognize that people expect to be able to present and facilitate with style. Like actors, most trainers feel exited before some event. Training professionals are involved in conducting training needs analysis (TNA) for the organization for which that work. (Beard, C and Wilson (2001))

2) Motivation given in the training becomes the determinant factor to lead in the changing of youth character

In the beginning, the training is conducted by building motivation from the participation of the participants that has also become the determinant factor. If the participant has internal motivation, it is then much easier to change their character into something better.

Motivation is the realm of the psychological which connects to the human resources (human resources), Beard, C. And Wilson JP (2001: 10) [18] states that human resource development is the study and practice to improve the capacity of individuals, groups, organizations through learning, and its effects is the development of the individual or organization's growth. Thus, the motivation and expectations of potential trainees and alumni training needs accommodated, is always contained in the form of a discussion forum and communications. Thus, will form a continuous training program and be accepted by society as an effective training and relevant to the needs.

\section{3) Strong communication and partnership}

Another strength as the determinant factor in building youth character in the training is good communication and coordination among the participants, tutor, management and the supervisory of the training, even with the 
partnership of the other parties such as society and partnership.

\section{CONCLUSION}

The management of SSG DT training which is conducted within three months' period every Saturday and Sunday aims to attain the goals of the youth character building to become good and strong. The good character built in the youth involves honest, sincere, and modest, while strong character includes brave, discipline, and firm.

The management of SSG DT training is started from the elements of supervisor, trainer, facilitator, and the teacher within each session every week while keeping doing the monitoring for the improvement of the program every week. The fostering program conducted in the trainer personnel and the management of training institution is consistently done every week so that the program that has been done and will be done can be coordinated.

The training program is done gradually, based on direction and continuity, started from self-breakthrough, self-building and team building. SSG training is conducted through some methods such as drilling, learning by doing, reflecting and experiential learning in understanding the lesson of each experience and occurrences done in the training that can be meaningful habits for the self-change to be a better person. Training place is set dynamically within each week in line with the step of the training and the program in the DT boarding school, in Eko Boarding school, UPI facilities and even in the society environment in the open. This research focuses on the investigation of the determinant factors building youth character in SSG Training. The results showed that determinant factors in building youth character through SSG training are as follows.

- Environment, in which the location of the research is in the area of boarding school which is full of religious values. Religious activities used as the materials for training, supported by the conducive and positive environment can strengthen participants to find his true self.

- Methods and techniques of training using methods that balance between physical and mental aimed to build good character (honest, sincere and modest) and strong character (brave, discipline, and firm). Training participants in every chance and every experience given to them are directed to gain a lesson and is always connected to the power of Allah SWT. The participants are always directed to keep remembering the position of a human in front of Allah and so that all participants are faced with the choice to be a better person who has BAKU character.

- The commitment of the trainer and facilitator to set good examples for the participants of the SSG training in which both trainer and facilitator have a solid commitment and continuously help participants to find their true character to be better people.

- Participants' motivation in which in self breakthrough stage, participants are assisted to open their mind and heart to motivate them to become better people. Those who are success to open their minds and hearts in the selfbreakthrough stage generally will keep continuing following the program and will follow the direction from the trainer.

\section{- Strong communication and partnership}

- Better coordination and communication internally within the institution and outside of the institution that support the program so that the training can result in training graduation for the youth as the participant of the training.

\section{REFERENCES}

[1] Data Susenas, 2009, Kemenegpora 2010

[2] Syamsudin, Aziz (2008). Kaum Muda Menatap Masa Depan Indonesia. Jakarta: Penerbit RM Books.

[3] M. Halstead (2004). "An Islamic Concept of Education”, Journal Comparative Education

[4] Catherine C. McDonald et All (2011). "Community Violence Exposure and Positive Youth Development in Urban Youth". Journal: Community Health.

[5] Brian D. Christens, N. Andrew Peterson. (2012). "The Role of Empowerment in Youth Development: A Study of Sociopolitical Control as Mediator of Ecological Systems' Influence on Developmental Outcomes". Journal: Youth Adolescence.

[6] Beard, C and Wilson J.P (2001). The Power of Experiential Learning: A Handbook for Educators and Trainers, London, Kogan Page

[7] Gymnastiar, A. (2013). Membangun Karakter BAKU (Baik dan Kuat). Bandung: SMS Tauhiid.

[8] Leslie, Rae (2000). Effective Planning in Training and Development, London: Kogan Page.

[9] Mulyasa, E. (2014). Manajemen Pendidikan Karakter. Jakarta: Bumi Aksara.

[10] Sauri, S. (2014). Model-Model Pembelajaran Berbasis Nilai Islam. Bandung: Sekolah Pascasarjana Universitas Pendidikan Indonesia.

[11] Sudjana. (2004). Manajemen Program Pendidikan. Bandung: Falah Production.

Other Resources:

[12] Kartadinata, S (2010), Mencari Bentuk Pendidikan Karakter Bangsa. online diunduh 24 mei 2010

[13] Kemdiknas: Policy Brief Dirjen Dikdas edisi: 4 (2011). Pendidikan Karakter untuk Membangun Karakter Bangsa. Jakarta: Dirjen Pendidikan Dasar, Kemdiknas.

Journal:

[14] Edmond P. Bowers et All (2010). "The Five Cs Model of Positive Youth Development: A Longitudinal Analysis of Confirmatory Factor Structure and Measurement Invariance". Journal: Youth Adolescence.

[15] G. John Geldhof et all (2014). "Longitudinal Analysis of A Very Short Measure of Positive Youth Development". Journal: Youth Adolescence

[16] Jennifer P. Agans et all (2014). "Activity Involvement as an Ecological Asset: Profiles of Participation and Youth Outcomes". Journal: Youth Adolescence

[17] N. Park. (2004). "Character Strengths and Positive Youth Development". Journal The Annals of the American Academy of Political and Social Science

[18] ----------(2009). "Building Strengths of Character: Keys to Positive Youth Development", Journal Reclaiming children and youth

[19] N. Park, C. Peterson. (2006). "Moral Competence and Character Strengths among Adolescents: The Development and Validation of The Values in Action Inventory of Strengths for Youth". Journal of adolescen 